\title{
LIBERDADE DE INFORMAÇÃO JORNALÍSTICA E O DIREITO DE CRÍTICA AOS GOVERNANTES: COMPARAÇÃO ENTRE PRIMEIRA REPÚBLICA E ORDEM CONSTITUCIONAL VIGENTE
}

\section{LIBERTÀ DI INFORMAZIONI GIORNALISTICA E IL DIRITTO DI CRITICA AI GOVERNANTI: CONFRONTO TRA PRIMA REPUBBLICA E L'ORDINE COSTITUZIONALE IN VIGORE}

\author{
${ }^{1}$ Pedro Augusto Lopes Sabino
}

\section{RESUMO}

O tema do presente artigo é a crítica aos governantes por meio do exercício da liberdade de informação jornalística. O presente trabalho busca aferir se o conteúdo atribuído a este direito foi alterado quando confrontada a Constituição atual com a de 1891. Formulou-se o seguinte problema: a crítica aos governantes por meio da imprensa, atualmente, recebe o mesmo tratamento jurídico observado no início do período republicano? Quanto ao método, utilizouse a comparação diacrônica. Conclui-se que houve uma mudança na orientação do Supremo Tribunal Federal no que concerne à proteção deste direito, com progressivo aumento dos requisitos para a responsabilização.

Palavras-chave: Liberdade de informação jornalística, Crítica aos governantes, Comparação entre constituição de 1891 e a constituição de 1988

\section{RESUMEN}

Il tema di questo articolo è la critica ai governanti attraverso l'esercizio della libertà di stampa. Questo studio si propone di valutare se il contenuto attribuito a tale diritto è stato cambiato quando si confronta l'attuale Costituzione de 1988 con la del 1891. Il seguente problema è stato formulato: la critica ai governanti attraverso la stampa attualmente riceve lo stesso trattamento giuridico osservato nel primo periodo repubblicano? Per quanto riguarda il metodo, è utilizzato il confronto diacronico. Si è concluso che c'è stato un cambiamento nella comprensione della Corte Suprema in materia di protezione di questo diritto.

Palabras-claves: Libertà di stampa, Critica ai governanti, Confronto tra la costituzione 1891 e la costituzione del 1988

\footnotetext{
${ }^{1}$ Mestre em Direito pela Faculdade de Direito Universidade Federal da Bahia - UFBA, Salvador. (Brasil). Professor Assistente da Universidade do Estado da Bahia - UNEB. E-mail: plopessabino@ gmail.com
} 


\section{INTRODUÇÃO}

A liberdade de pensamento e o correlativo direito de expressá-lo tem reiteradamente ocupado o centro do debate público. Diversas questões se relacionam à sua discussão: da expressão simbólica de crítica a uma ação governamental por meio da queima de bandeiras ao uso de símbolos reveladores de orientação política e religiosa, passando-se pela divulgação de informações classificadas como sigilosas por envolverem a segurança do Estado. Estes e inúmeros outros casos oferecem a oportunidade de debater o conteúdo jurídico do direito em questão.

No presente trabalho, pretende-se verificar um aspecto: a crítica aos governantes por meio da imprensa. Especificamente, o presente trabalho busca aferir se o conteúdo atribuído à liberdade de imprensa foi alterado ao longo da história republicana do Brasil. Vale dizer, o problema posto é o seguinte: a crítica aos governantes por meio da imprensa atualmente, na vigência da Constituição Federal de 1988 (CF), recebe o mesmo tratamento jurídico observado no início do período republicano, sob o pálio da Constituição de 1891 (CR/1891)?

A opção pelo período republicano é justificável, haja vista a relação dos indivíduos com o Estado ser posta em outros termos em comparação com os súditos da realeza. A república, na história constitucional brasileira, trouxe à tona a ênfase em um conjunto de prerrogativas da cidadania oponíveis ao Estado, máxime a participação política na formação da vontade estatal. Ademais, corolário do princípio republicano é a responsabilidade dos agentes públicos. Tais fundamentos justificam a delimitação temporal do presente texto.

Pretende-se demonstrar que a evolução constitucional brasileira consagrou o amplo direito de crítica aos governantes, particularmente por meio da imprensa. O cidadão, para exercer qualquer aspecto do seu direito de liberdade necessita de acesso à informação. $\mathrm{O}$ pleno exercício da cidadania é dependente de um debate público aberto, plural, profundo acerca das questões que interessam à coletividade. Nesse sentido, a crítica à atuação governamental revelou-se indissociável do exercício da cidadania e, dada a grande extensão territorial do Estado, não pôde dispensar o potencial dos meios de comunicação de massa para atingir o maior número de pessoas possível.

No que concerne ao método, utilizou-se a comparação diacrônica (SILVA, 2009, p. 23-24) ${ }^{1}$, confrontando-se o texto constitucional e decisões do Supremo Tribunal Federal

\footnotetext{
${ }^{1}$ José Afonso da Silva utiliza a terminologia comparação diacrônica ou vertical para se referir ao cotejamento de uma mesma comunidade em épocas distintas e comparação sincrônica ou horizontal para se referir a ordens jurídicas distintas de uma mesma época. Jorge Miranda, com o mesmo propósito, utiliza a terminologia
} 
(STF) proferidas sob a vigência da CR/1891 com recentes decisões proferidas após a CF. A utilização do método comparativo se mostrou necessária para se verificar se houve uma estagnação do âmbito de proteção da liberdade de imprensa ou se, diversamente, ao longo da história constitucional republicana brasileira houve ampliação da esfera protegida por este direito.

A resposta ao problema escolhido para o presente trabalho não exige uma comparação sincrônica (SILVA, 2009, p. 23-24). Mesmo não sendo indispensável ao teste da hipótese, a referência a outros paíse foi ocasionalmente feita com o propósito de incorporar discussões desenvolvidas alhures à realidade nacional (ROSINA, 2014, p. 131-133). As referências à experiências estrangeiras buscou observar, por um lado, a família jurídica e o sistema jurídico no qual se insere o Brasil; por outro lado, a convergência de sistemas que tem promovido a reflexão sobre o intercâmbio entre famílias jurídicas distintas (VICENTE, 2008, p. 98-99), bem como a indiscutível influência americana sobre o constitucionalismo republicano brasileiro justificam o exame de algumas decisões proferidas pela Suprema Corte norteamericana.

Para responder à questão formulada, inicialmente, será feito o exame de decisões proferidas pelo STF na primeira fase do período republicano brasileiro. Em seguida, será demonstrado o atual entendimento da Corte de modo a ser feito uma comparação entre os dois períodos.

As decisões foram escolhidas de modos diferenciados. As três decisões proferidas sob a vigência da CR/1891 foram todas as encontradas à disposição na página do STF na internet. As três decisões mais recentes foram selecionadas qualitativamente, entre julgados citados em outros trabalhos lidos.

\section{LIBERDADE DE IMPRENSA NA CONSTITUIÇÃO DE 1891}

Antes do período republicano, a Constituição Política do Império do Brasil de 1824 já inseria entre as garantias dos direitos civis e políticos dos brasileiros a possibilidade de publicação dos seus pensamentos por meio da imprensa:

Art. 179. A inviolabilidade dos Direitos Civis, e Politicos dos Cidadãos

comparação sucessiva e comparação simultânea (2011, p. 1267-1269). A denominação comparação sucessiva também é utilizada para ordens jurídicas distintas em épocas distintas (comparação, simultaneamente, no tempo e no espaço). Este trabalho de Jorge Miranda foi originalmente publicado na Revista de Direito Constitucional e Internacional, RDCI 55/243, abr.-jun./2006. 
Brazileiros, que tem por base a liberdade, a segurança individual, e a propriedade, é garantida pela Constituição do Imperio, pela maneira seguinte.

IV. Todos podem communicar os seus pensamentos, por palavras, escriptos, e publical-os pela Imprensa, sem dependencia de censura; com tanto que hajam de responder pelos abusos, que commetterem no exercicio deste Direito, nos casos, e pela fórma, que a Lei determinar.

Adotou-se um princípio há muito defendido por John Milton na obra Areopagítica, em 1644: a liberdade prévia conjugada com a responsabilidade posterior. Nesse sentido, em sua crítica à necessidade de autorização prévia para se imprimir, ele defendeu que nenhum livro seria impresso a não ser que explicitasse os nomes do impressor e do autor ou, pelo menos, com o do impressor. Desse modo, seria possível responsabilizar eventuais abusos (MILTON, 1999).

A CR/1891 manteve o mesmo princípio expresso em sua declaração de direitos, tanto na redação original do art. $72, \S 2^{\circ}$, quanto na redação dada pela Emenda Constitucional n. 3 de 1926:

Art.72 - A Constituição assegura a brasileiros e a estrangeiros residentes no país a inviolabilidade dos direitos concernentes à liberdade, à segurança individual e à propriedade, nos termos seguintes: (Redação dada pela Emenda Constitucional de 3 de setembro de 1926)

$\S 12$. Em qualquer assumpto é livre a manifestação do pensamento pela imprensa ou pela tribuna, sem dependencia de censura, respondendo cada um pelos abusos que commetter, nos casos e pela fórma que a lei determinar. Não é permittido o anonymato. (Redação dada pela Emenda Constitucional de 3 de setembro de 1926)

Sob a vigência da CR/1891, três decisões proferidas pelo STF devem subsidiar a análise desenvolvida no presente trabalho: o HC 3536, de 1914, relativo à publicação de discursos parlamentares durante o estado de sítio; o HC 4781, de 1919, no qual se discute a liberdade de manifestação durante eleição; e o Recurso 491, de 1923, cujo objeto de discussão é acusação dirigida ao ex-Presidente. Destas, a última trata especificamente do problema formulado enquanto as duas outras fornecem subsídios para a compreensão do entendimento sobre a matéria adotado na época.

\subsection{HC 3536 dE 1914}

O HC 3536 teve como impetrante e paciente o senador Ruy Barbosa. Impetrado com o propósito de garantir o exercício do direito de criticar a ação do governo por meio da qual 
foi prorrogada a duração do estado de sítio por mais seis meses, nele se defendeu que este direito era necessário ao cumprimento dos seus deveres como senador da República. Durante a sessão, no Senado, o impetrante fez discurso de protesto contra o ato do Governo que teria infringido preceitos constitucionais e forneceu cópia datilográfica ao jornal $O$ Imparcial para ser dado conhecimento ao público.

O redator do jornal $O$ Imparcial teria sido proibido por autoridade pública vinculada ao Executivo de publicar os debates do Congresso Nacional. Tal ação teria condenado o discurso parlamentar à clausura ou reduzido "aos limites mesquinhos da publicidade official, inaccessível ao povo"; o que atentaria contra os direitos do Poder Legislativo em geral e contra cada um de seus membros em particular, bem como contra a separação de poderes expressa no art. 15 da CR/1891.

De acordo com a leitura do Acórdão, a liberdade de ir, vir e permanecer do senador não foi ameaçada. Como representante da soberania nacional, o senador estaria "isento da acção do Poder Executivo", mesmo durante o estado de sítio, sob pena de se admitir uma ascendência de um poder contra o outro. O que estava em questão era o fato do senador sofrer ou se encontrar sob iminente perigo de sofrer violência ou abuso de poder. Por conseguinte, antes da criação do mandado de segurança, este caso exemplifica a aplicação da célebre doutrina brasileira do habeas corpus (art. 72, § 22, da CR/1891).

O STF, por maioria, entendeu que privar um senador da possibilidade de publicação de seus discursos na imprensa importaria "em manifesta restricção na sua liberdade de representante da Nação", porque o seu mandado deveria ser exercido em sessões públicas, valendo-se da palavra falada dirigida aos seus representados. De acordo com os fundamentos acolhidos na decisão, seria da essência do regime político adotado a publicidade dos debates legislativos, porque os poderes políticos surgiriam da "Nação no exercício da soberania" e esta precisaria "saber como agem seus representantes".

$\mathrm{Na}$ fundamentação da decisão, afirmou-se, também, que a publicação dos discursos restrita à imprensa oficial sob a fiscalização do Executivo "anularia" a publicidade. Evidentemente, a terminologia "anulação" não foi a mais adequada. Certamente, objetivou-se afirmar que o objetivo de dar ampla publicidade aos atos dos representantes não seria atingido valendo-se, apenas, da publicação oficial, sem a divulgação por meio dos veículos de comunicação aptos a atingir a grande maioria da população.

Ao final, o STF decidiu conceder a ordem de modo a assegurar ao senador o seu direito constitucional de publicar os seus discursos, pela imprensa, onde, como e qua ndo lhe conviesse, não se restringindo às publicações oficiais. Como consequência necessária, os 
jornalistas interessados em publicar os discursos do Congresso eventualmente ameaçados de coação ilegal à sua liberdade individual também seriam protegidos pela garantia do habeas corpus $^{2}$.

Saliente-se que este direito não foi amplamente assegurado a qualquer cidadão. A fundamentação da decisão, sem embargo da referência à soberania popular e ao regime republicano, orbitou o princípio da separação de poderes. A proteção ao direito de crítica aos governantes, mesmo durante o estado de sítio, foi assegurada a um parlamentar e apenas de maneira indireta aos jornalistas - protegidos quando publicassem os discursos dos parlamentares.

\subsection{HC 4781 de 1919}

Em 1919, o STF decidiu caso relacionado à liberdade de manifestação de pensamento (HC 4781) no contexto das eleições presidenciais de 1919. Na ocasião, o senador Ruy Barbosa, correligionários políticos e amigos, ao tentarem se reunir em comícios, nas ruas, praças, teatros e qualquer outro recinto, eram ameaçados de sofrer violência, impedidos e coagidos, por abuso de autoridade dos poderes públicos do Estado da Bahia, notadamente na capital do Estado-membro.

As ameaças seriam amplamente conhecidas e contribuiriam para a situação de pânico em que se encontraria a população da capital baiana. Entre os telegramas que circulavam nesse contexto de acirrado embate político, mereceria destaque o que anunciaria o "propósito firme em que se acham o senador Seabra e seus adeptos de comparecer às reuniões convocadas pelos amigos do impetrante, afim de apartearem aos oradores e, principalmente, ao próprio candidato da Nação, quando este se referir ao Governo do Estado" (BRASIL, 1919, p. 1). Mais uma vez, a crítica aos governantes seria objeto de apreciação pelo STF dessa vez, sem vigência de estado de sítio e não restrita à garantia de prerrogativas de parlamentares.

Em publicação do Jornal do Comércio da Capital, o chefe de Polícia "suprimiu as liberdades de reunião e de pensamento, garantidas pelos parágrafos oitavo e duodécimo do art. 72 da Constituição Federal”. Submetida a matéria à apreciação do STF, o julgamento foi desenvolvido de modo a serem apreciados os seguintes aspectos: se a questão seria da

\footnotetext{
${ }^{2}$ A fundamentação dos votos vencidos se restringiu, de uma parte, na recusa da doutrina brasileira do habeas corpus, com expressa referência à doutrina estrangeira que restringia o uso do writ à liberdade de locomoção. Superada essa questão, no mérito, um ministro defendeu a possibilidade de medidas restritivas impostas durante o estado de sítio atingirem até mesmo parlamentares.
} 
competência originária da Corte; se o habeas corpus seria cabível; e se os requisitos da ação proposta estavam provados.

O relator do caso deixou clara a competência do STF para julgamento com fulcro no art. 23 da Lei n. 221/1892. No que concerne ao cabimento do habeas corpus para a garantia do direito em questão, salientou que a maioria da Corte firmara o entendimento no sentido de que seria o writ "competente para proteger o exercício de qualquer direito, desde que este seja certo, líquido e incontestável” (BRASIL, 1919, p. 2). Nota-se, mais uma vez, a adesão do Tribunal à doutrina brasileira do habeas corpus. Enfatizou-se que, mesmo para a minoria da Corte, para a qual o habeas corpus seria cabível apenas para proteger a liberdade corpórea ou a faculdade de livre locomoção, o pedido deveria ser deferido. $\mathrm{O}$ art. $72, \S \S 8^{\circ}$ e $12^{\circ}$, da Constituição Federal assegurariam o direito cuja garantia estava sendo pleiteada: "é certo, líquido e incontestável o direito que têm todos os indivíduos de se associarem e de se reunirem, livremente e sem armas, para manifestarem seu pensamento pela tribuna, sem dependência de censura, não podendo a polícia intervir senão para manter a ordem pública" (BRASIL, 1919, p. 3).

O relator do caso explicitou três direitos vinculados ao exame da liberdade ameaçada: "o de permanecer o indivíduo em qualquer lugar, à sua escolha, desde que seja franqueado ao público"; "o de ir de qualquer parte, para esse lugar"; e "o de vir, para ele, também, de qualquer outro ponto". A proibição dos comícios afetaria todos os três direitos mencionados (BRASIL, 1919, p. 3).

A prova dos requisitos autorizadores da concessão da ordem de habeas corpus em sua acepção clássica também seriam comprovados, até mesmo por publicação oficial. As respostas encontradas às questões inicialmente formuladas pela Corte conduziram à concessão da ordem favorável a Ruy Barbosa e a todos os indivíduos mencionados nominalmente na inicial, garantindo a possibilidade de exercício do direito de reunião e "da palavra nas praças, ruas, teatros e quaisquer recintos, sem obstáculos de natureza alguma".

A Constituição da República expressamente asseguraria a todos os direitos de se associarem e se reunirem livremente e sem armas, não sendo possível a intervenção policial exceto para manter a ordem pública $\left(\mathrm{CR} / 1891\right.$, art. 72, $\left.\S 8^{\circ}\right)$. A Constituição também asseguraria a "livre a manifestação de pensamento pela imprensa ou pela tribuna, sem dependência de censura, respondendo cada um pelos abusos que cometer, nos casos e pela forma que a lei determina" (CR/1891, art. 72, § 12). Ademais, a legislação infraconstitucional afastaria a caracterização de sedição quando se tratasse de uma "reunião pacífica e sem armas do povo nas praças públicas, teatros e quaisquer outros edifícios ou lugares convenientes 
para exercer o direito de discutir e representar sobre os negócios públicos" (Código Penal, art. 123). Além disso, a maioria da Corte entendeu não ser prerrogativa da polícia determinar o local de realização dos meetings ou comícios (Código Penal, art. 123, parágrafo único) (BRASIL, 1919, p. 5-6). Todos esses fundamentos foram utilizados pelo STF em sua decisão.

No que concerne aos votos vencidos, houve a divergência parcial por parte de alguns magistrados. Alguns defenderam a impossibilidade de conhecimento originário da causa pelo STF e a possibilidade de a polícia localizar os meetings, bem como adotar outras medidas reputadas necessárias à manutenção da ordem pública (BRASIL, 1919, p. 6).

Nesse acórdão, a livre manifestação do pensamento pela imprensa, apesar de mencionada nos fundamentos, não foi o ponto central da argumentação. É certo que a reunião com propósito político também é uma forma de expressão. Ainda que não traduzida no vernáculo, a participação em manifestação política traduz uma expressão simbólica.

Cumpre salientar, mesmo não tendo sido o objeto da deliberação, a ressalva feita pelo relator ao afirmar a possibilidade de participação de grupo político rival no evento com o propósito de apartear "ao impetrante ou a quem quer que seja que, a favor de sua candidatura, fale em público". De acordo com este, seria "um percalço de quem fala em comícios públicos sujeitar-se a apartes de quem se achar em desacordo com suas ideias" (BRASIL, 1919, p. 34). Ao se compreender a matéria desse modo, o risco de confronto entre grupos políticos em disputa e de comprometimento da ordem pública disso decorrente é acentuado.

\subsection{Recurso 491 de 1923}

O Jornal Correio da Manhã, publicou acusação contra o ex-Presidente da República Epitácio da Silva Pessoa, por motivo relacionado ao exercício de suas funções. Ao considerarse caluniado e injuriado, o ex-Presidente recorreu ao Judiciário para desagravar-se. Sucede que o juiz de primeira instância se julgou incompetente e, em sede recursal, a matéria chegou ao STF.

A publicação atribuiu ao ex-agente estatal a prática de abusos ou mesmo crime no exercício de atribuições que lhe foram confiadas para o benefício de toda a coletividade. $\mathrm{Na}$ qualidade de Presidente de República, teria recebido suborno em troca da expedição de um decreto destinado a favorecer interesses ilegítimos (BRASIL, 1923, p. 7-10).

O STF proferiu decisão favorável ao recorrente ao entender o juízo a quo competente para o julgamento e remeter o processo com o propósito de assegurar o recebimento da queixa e o prosseguimento do processo. 
O debate se concentrou na questão da competência da Justiça Federal para o julgamento do caso após o fim do mandato presidencial. Em algumas passagens, a decisão faz referências a abuso da liberdade de pensamento pela imprensa, sem dilucidar a compreensão sobre a matéria. A própria ementa do acórdão dá um destaque ao tema muito maior do que o debate entre os membros da Corte. Não obstante este fato, salienta que a importância da liberdade de imprensa ocasionou a admissão da exceção da verdade na defesa contra a suposta prática do crime de injúria:

É essa uma situação excepcional, creada por um motivo relevante de interesse publico, pois a exceptio veritatis é permitida, nesse caso, em consideração ao principio da liberdade de imprensa, essencial ao jogo e funccionamento normal dos institutos politicos democraticos e prende-se ao principio constitucional que institui a acção popular para a denuncia dos abusos das autoridades e para a promoção da responsabilidade respectiva.

Essa fiscalização publica dos depositários do Poder seria, a cada passo, entravada e, a todo momento, cerceada, si, applicadas ao jornalista, que quasi monopolisa aquella fiscalização, as regras comuns relativas ao crime de injuria, lhe não fosse permittida a defesa fundada na prova das suas assacadilhas, não raro apaixonadas, contra os detendores do poder e encarregados da administração publica.

Tal defesa, permittida por uma razão de interesse collectivo, póde verificarse sempre, esteja ou não o queixoso no exercício das suas funcções, porque aquella razão subsiste em ambos os casos (BRASIL, 1923, p. 14).

A possibilidade de prova da verdade, aplicável aos funcionários públicos em geral, sofria uma restrição em relação ao Presidente da República. Quanto a este, a Lei de Imprensa vigente à época conferiu o privilégio, destacado por um dos julgadores, de não admitir a prova da verdade, exceto quando não se tratasse de calúnia ou injúria:

Na verdade, a Lei de imprensa cercou o Presidente da Republica das maiores regalias, dos privilegios mais extraordinarios que se poderiam imaginar.

Basta dizer que não se admitte prova da verdade das imputações que lhe tenham sido feitas, uma vez que essas imputações sejam offensivas, embora não cheguem a constituir calumnia ou injuria, ficando ao arbitrio do Juiz a consideração do que seja uma offensa que não revista os caracteres da calumnia ou da injuria. É a disposição do art. $1^{\circ} \S 3^{\circ}$, combinado com o artigo $3^{\circ}$ da Lei (BRASIL, 1923, p. 26).

Esta impossibilidade de prova da verdade traduziu restrição à liberdade de imprensa, notadamente quando não se apresentam, claramente, os seus limites. Nenhum membro do STF suscitou a possível incompatibilidade desta disposição normativa com a ordem constitucional vigente. 


\subsection{Evolução da Proteção da Imprensa nos Estados Unidos}

Diferentemente da experiência brasileira, nos Estados Unidos, de acordo com Anthony Lewis, uma série de decisões da Suprema Corte marcou a progressiva mudança do seu entendimento no sentido de se reconhecer a possibilidade de erro cometido pela imprensa dentro do âmbito de proteção da Primeira Emenda (relacionada à liberdade de expressão). Este posicionamento demorou décadas para ser reconhecido e convém confrontá-lo com o entendimento firmado pelo STF.

Antes da independência, em conformidade com a legislação inglesa, havia o crime de difamação sediciosa, que inibia a crítica aos agentes do Estado ao não admitir a prova da verdade da acusação. Após a independência, em 4 de julho de 1789, a difamação sediciosa se tornou crime federal. Formalmente, a Lei de Sedição era motivada pelo combate ao terrorismo, ao terrorismo francês associado aos desdobramentos da Revolução Francesa; efetivamente, a lei foi criada "para reprimir comentários favoráveis a Jefferson na campanha para a eleição presidencial de 1800, quando Jefferson concorreria com Adams [então presidente, candidato à reeleição]". Apesar da Lei de Sedição admitir a prova da verdade, na prática, ela inibia a imprensa tal qual a difamação sediciosa do common law inglês (LEWIS, 2011, p. 27-29).

A discussão acerca da possibilidade de crítica aos governantes persistiu sem uma decisão. Na época, Madison, fundado na ideia de soberania popular, defendeu como premissa do sistema político norte-americano o direito de examinar livremente medidas e personagens públicos (LEWIS, 2011, p. 34-35). Esta lei nunca chegou a uma decisão definitiva da Suprema Corte, “A Lei de Sedição de 1798 foi efetivamente rejeitada pelos eleitores na eleição de 1800” (LEWIS, 2011, p. 218), que elegeram o candidato oposicionista:

\footnotetext{
A Lei de Sedição acabou dando uma contribuição significativa à liberdade americana. Ela fez com que grande número de americanos valorizasse a importância da liberdade de expressão e de imprensa em uma república: a premissa de Madison. Fosse ou não a intenção dos autores da Primeira Emenda eliminar o crime de difamação sediciosa, dez anos depois de ela ter sido adicionada à Constituição a opinião dos americanos era que tal crime era incoerente com os valores constitucionais. Mas uma característica da Lei de Sedição não desapareceu: o uso político do medo para justificar a repressão (LEWIS, 2011, p. 37, negritos nossos).
}

As liberdades de impressa e de expressão ganharam relevo no ordenamento norteamericano no século 20. Até então, as cláusulas de liberdade de imprensa e expressão não 
eram "questão jurídica séria" em debate. Até então, a Suprema Corte permitia repressões em determinados casos. As condições para a mudança do entendimento da Corte começaram a ser alteradas quando passaram a defender que os direitos da Primeira Emenda, com base na Décima Quarta Emenda (devido processo legal), deveriam ser assegurados contra os Estados- membros. (LEWIS, 2011, p. 39-41).

Na década de 1930, mais de cem anos após a promulgação da Constituição, a maioria da Suprema Corte passou a considerar que a Primeira Emenda ${ }^{3}$ deveria ser imposta a todos assim como uma lei - em Stromberg vs California. Sucedeu esta decisão a intensificação do debate sobre a definição da liberdade protegida pela Primeira Emenda (LEWIS, 2011, p. 57).

Firmou-se o entendimento de que a redação deliberadamente abrangente da Primeira Emenda objetivou conferir à liberdade uma proteção abrangente, sem a intenção de fornecer um rol de limitado de possibilidades. A proteção da livre discussão pública destinada a apurar a responsabilidade do governo e permitir ao povo a conquista de mudanças pelos meios legais, seguindo-se a argumentação desenvolvida por Oliver Wendell Holmes Jr. e Louis D. Brandeis na década anterior, foi reconhecida como um princípio fundamental. Essa proteção abrangente também compreenderia “expressões que não são literalmente proferidas ou impressas" - o discurso simbólico (LEWIS, 2011, p. 57-59).

Em 1931, em Near vs Minnesota, praticamente se afastou a possibilidade de uma ordem de restrição prévia contra um veículo da imprensa. Mesmo diante do risco de as afirmações contra funcionários públicos serem falsas, não se admitiu a proibição prévia. Neste caso, um editor supostamente antissemita denunciou um conluio entre criminosos judeus e funcionários públicos e teve o jornal fechado (Saturday Press). Por 5 a 4, a Suprema Corte “decidiu que a interdição do Saturday Press viola a Primeira Emenda tal como aplicada aos estados pela Décima Quarta" (LEWIS, 2011, p. 61-65):

Pouco tempo depois, em 1936, por unanimidade, em Grosjean vs American Press Co, a Suprema Corte declarou inconstitucional um imposto criado em Louisiana destinado a punir os jornais que o criticassem. A decisão da Corte foi fundamentada na função informativa da imprensa, que asseguraria o direito dos cidadãos de conhecer os acertos e desacertos do seu governo (LEWIS, 2011, p. 65).

Um grande marco para a proteção da imprensa nos Estados Unidos, particularmente

\footnotetext{
3 "Congress shall make no law respecting an establishment of religion, or prohibiting the free exercise thereof; or abridging the freedom of speech, or of the press; or the right of the people peaceably to assemble, and to petition the Government for a redress of grievances"/" O Congresso não fará leis relativas ao estabelecimento de religião ou proibindo-lhes o livre exercício; restringindo a liberdade de palavra ou imprensa; ou o direito do povo reunir-se pacificamente e de requerer ao governo o ressarcimento de danos sofridos".
} 
no que concerne à responsabilidade por acusações falsas contra agentes públicos, foi o caso New York Times vs Sullivan, de 1964. O debate sobre as restrições prévias já estava, como visto, superado. Permanecia como questão constitucional relevante para a imprensa a responsabilidade posterior pelas publicações. Nesta oportunidade, a Suprema Corte admitiu a possibilidade de afirmações errôneas divulgadas por meio da imprensa não serem seguidas de responsabilização civil: "afirmações errôneas são inevitáveis em um debate livre, e [...] devem ser protegidas se quisermos que as liberdades de expressão tenham o espaço para respirar de que necessitam para sobreviver" (LEWIS, 2011, p. 33).

O jornal New York Times publicou informações imprecisas, relacionadas à participação de funcionários públicos racistas do Sul que teriam criado dificuldades ilegais às manifestações do movimento pelos direitos civis liderado por Martin Luther King Jr., caracterizadoras de difamação para a legislação do estado do Alabama e foi processado. Em conformidade com a tradição do common law e com regras adotadas em vários estados, o ônus da prova da verdade seria do jornal, o dano do alvo da publicação seria presumido e o erro do responsável pela publicação também seria presumido (LEWIS, 2011, p. 68-69). Uma sequência de indenizações relacionadas ao caso poderia fechar o jornal e desencorajar a cobertura por outros jornais ao movimento pelos direitos civis por causa dos riscos o que afetaria o propósito informativo da Primeira Emenda. A defesa argumentou que não poderia ser exigida prova da verdade para críticas dirigidas aos ocupantes de cargos públicos. Em síntese, o medo do erro não poderia desencorajar a livre discussão pública. Pela primeira vez, o julgamento foi favorável a quem praticou a difamação (LEWIS, 2011, p. 67-77).

O juiz Willian J. Brennan Jr. defendeu um compromisso nacional com o princípio apto a garantir um debate de questões públicas irrestrito, robusto e aberto, ainda que pudesse ocasionalmente compreender ataques contundentes ao governo e aos funcionários públicos (LEWIS, 2011, p. 72). Nesse sentido, defendeu requisitos restritivos da possibilidade de ocupantes de cargos públicos receberem de seus críticos indenização por difamação:

... os ocupantes de cargos públicos não poderiam receber de seus críticos indenização por difamação, a menos que provassem que uma afirmação danosa e falsa tivesse sido feita com conhecimento de sua falsidade - uma mentira deliberada - ou por "desconsideração imprudente" de sua verdade ou falsidade. Casos posteriores explicaram que "desconsideração imprudente" significava que o autor ou o responsável pela publicação estava ciente da provável falsidade da afirmação feita (LEWIS, 2011, p. 73, negritos nossos).

De acordo com Anthony Lewis, o caso New York Times vs Sullivan "revolucionou a 
legislação sobre difamação nos Estados Unidos. O que sempre havia sido uma questão de legislação estadual passou, na maioria dos casos, a depender do direito constitucional federal". A partir de então, para vencer "o querelante tinha de provar a falsidade - e provar a culpa por parte do autor ou responsável pela publicação, e não apenas um erro inocente" (2011, p. 74). Vale dizer, "afirmações foram publicadas ou transmitidas com conhecimento ou grave negligência (reckless disregard) sobre a sua falsidade" (FISS, 2005, p. 100).

Owen Fiss também destaca a importância e analisa a decisão de New York Times $v$. Sullivan. A Suprema Corte restringiu a capacidade estatal de proteger a reputação de agentes públicos (contravalor) em confronto com a liberdade de expressão. Os agentes públicos, ao adentrarem na arena política, assumiriam certos riscos à sua reputação $(2005, \mathrm{p}$.

36). O julgamento passou a ser considerado o precedente mais importante da autonomia jurídica da imprensa, ao impor limites à capacidade de o Estado silenciar os seus críticos. Entendeu-se que "a imprensa não pode ser criminalmente processada por difamar o Estado como entidade abstrata" (2005, p. 100, 108).

De acordo com Owen Fiss, na sociedade moderna, a imprensa organizada talvez seja a principal instituição a desenvolver a função de informar e avaliar políticas em andamento e práticas governamentais. Para cumprir as suas responsabilidades, "a imprensa necessita de certo graus de autonomia em relação ao Estado". A autonomia da imprensa pode ser econômica (imprensa americana não é dependente do Estado para fundos, os "oficiais governamentais" não podem manipular a imprensa) e jurídica (desenvolveu-se jurisprudência limitativa da capacidade de o Estado silenciar os seus críticos). O caso New York Times v. Sullivan se firmou como o mais importante precedente da afirmação desta autonomia jurídica da imprensa em face do Estado (2005, p. 99-101).

José Carlos Souto, ao examinar decisões da Suprema Corte americana relacionadas às liberdades públicas frisa a "linha tênue" entre o sacrifício da liberdade de imprensa e contravalores a serem preservados na ordem constitucional mediante sopesamento em cada caso concreto. A liberdade de imprensa, apesar de alicerce da democracia, não seria um direito absoluto e, por conseguinte, não se teria uma solução estática pré-definida. Contudo, "a interpretação deverá sempre buscar a valorização dos direito e garantias individuais, entre os quais se inclui o conjunto de Liberdades Públicas conhecido a partir do século XVIII e ampliado desde então" (2008, p. 149-150). Sem embargo do valor dessa assertiva, não se pode olvidar o caráter instrumental dos direitos em questão que, como poderá ser observado, adquiriram contornos transindividuais a serem observados, igualmente, por ocasião de eventual sopesamento. 


\subsection{Crítica à Proteção da Imprensa na Primeira República}

As decisões do STF na primeira fase do período republicano não diferenciam em esferas distintas as liberdades de expressão, de informação e de comunicação. Por conseguinte, apensar da menção reiterada à imprensa, não se verifica um tratamento específico ao feixe de direitos que lhe são próprios.

Jorge Miranda diferencia liberdade de expressão, de informação e de comunicação. A liberdade de expressão é definida nos seguintes termos: "A liberdade de expressão abrange qualquer exteriorização da vida própria das pessoas: crenças, convicções, ideias, ideologias, opiniões, sentimentos, emoções, actos de vontade. E pode revestir quaisquer formas: a palavra oral ou escrita, a imagem, o gesto [art. $74^{\circ}$, n. $2^{\circ}$, alínea $h$ ], o silêncio" (2000, p. 453).

A liberdade de informação teria em vista a "interiorização de algo externo", consistiria em "em apreender ou dar a apreender factos e notícias e nela prevalece o elemento cognoscitivo". Esta liberdade se desdobraria em três direitos: de informar, de se informar e de ser informado. O exercício do primeiro corresponderia a uma atitude "ativa e relacional", o segundo a uma atitude "activa e pessoal"; e o terceiro a uma atitude "passiva e receptícia" (MIRANDA, 2000, p. 454-455).

A liberdade de comunicação social conglobaria as liberdades de expressão e de informação com três notas distintivas: a pluralidade de destinatários, sem reciprocidade; o princípio da máxima difusão; a utilização de meios adequados (MIRANDA, 2000, p. 456).

A partir dessa dessas considerações, Jorge Miranda destaca características distintas dos direitos mencionados linhas acima. Enquanto a liberdade de expressão, o direito de se informar e o de ser informado são individuais, mesmo quando exercidos coletivamente, o direito de informar tanto pode ser individual quanto institucional. Por outro lado, a liberdade de comunicação é, "necessariamente, institucional, visto que pressupõe organização (e organização de empresa)". Além disso, as liberdades de expressão e de informação "situam-se de pleno no campo dos direitos fundamentais", enquanto a liberdade de comunicação social envolve um conjunto de direitos e também se relaciona com o fenômeno do poder. Ademais, situando-se na esfera da comunicação social, as posições dos cidadãos em geral e as dos jornalistas em particular são acentuadamente distintas (2000, p. 456-457).

Conforme assevera Jorge Miranda, no século XIX, a imprensa correspondia à imprensa escrita e a liberdade de informação não adquirira autonomia em face da liberdade de expressão. Nessa época, os fatores individuais prevaleciam sobre os empresariais e o Estado 
interferia apenas a posteriori, por meio da justiça criminal (2000, p. 458). Este ponto de vista é refletido nas decisões do STF mencionadas acima e demonstram uma cosmovisão jurídica, para os dias de hoje, limitada, incapaz de atender às demandas contemporâneas. Atualmente, tal como preleciona Jorge Miranda, "a liberdade de informação adquire relevo crescente ligado à formação da vontade popular” (2000, p. 458).

Marcelo Caetano afirma que a "liberdade tende a ser a expressão da limitação do Poder político". Afirma o autor a necessidade de distinguir dois conceitos fundamentais: " $a$ liberdade como atributo da pessoa, na qual se encontra essencialmente a disponibilidade pelo indivíduo das suas faculdades pessoais e dos seus bens"; e a "liberdade como instrumento de defesa ou de garantia da fruição e disposição dessas faculdades e desses bens" - também denominada de liberdade instrumental ou liberdade-participação (1998, p. 308-309). A liberdade de comunicação social e a liberdade de informação do ponto de vista institucional são indissociáveis do conceito de democracia e apresentam caráter nitidamente instrumental.

Esta nova compreensão dos direitos em jogo conduziu a uma diferenciação na Constituição portuguesa de 1976 entre o regime geral das liberdades de expressão e de informação, nos quais, até certo ponto, prevalece uma concepção liberal clássica, e o regime da liberdade de comunicação social, "em que se adoptam medidas intervencionistas, para garantia do pluralismo" (MIRANDA, 2000, p. 461). Esta nova visão sobre o tema, mais recentemente, tem se difundido também no Brasil.

Jorge Miranda, ao discorrer sobre a estrutura constitucional da democracia, destaca o direito de informação política, como uma "manifestação qualificada do direito dos cidadãos de se informar, sem impedimentos nem discriminações". Seria assegurado aos cidadãos (art. $48^{\circ}$, n. $2^{\circ}$, da Constituição portuguesa de 1976) o direito de serem esclarecidos objetivamente sobre atos do Estado e demais entidades públicas, bem como sobre a gestão dos assuntos públicos (MIRANDA, 2007, p. 115) ${ }^{4}$. Pode-se dizer que este é um desdobramento da nova compreensão do direito de liberdade, notadamente no que diz respeito à informação.

Como pode ser visto, nas duas primeiras decisões do STF a dimensão individual da liberdade de informação é a tônica dos julgamentos. Na terceira decisão, não se observa qualquer indício de um tratamento mais benéfico à imprensa quando comparada com fontes de informação de caráter individual ou mesmo de maior possibilidade de perscrutar a esfera de ação de agentes públicos. Em síntese, não se vislumbra um debate dirigido à afirmação da autonomia jurídica da imprensa em face do silenciamento dos críticos pelo Estado, dos

\footnotetext{
${ }^{4}$ Acerca deste dispositivo constitucional e dos componentes essenciais do direito de tomar parte na direção dos negócios públicos, leia-se José Joaquim Gomes Canotilho e Vital Moreira (2007, p. 663-667).
} 
direitos institucionais da imprensa ou da liberdade de comunicação social como direito e poder.

\section{LIBERDADE DE IMPRENSA NA CONSTITUIÇÃO FEDERAL DE 1988}

A CF conferiu ampla proteção à liberdade de informação jornalística ${ }^{5}$. Diversos dispositivos constitucionais auxiliam esta compreensão da proteção ${ }^{6}$.

A liberdade de expressão, independente de censura prévia, como já se demonstrou, estava presente no texto constitucional de 1891. A vedação do anonimato revela a ideia de responsabilidade posterior também verificada anteriormente. Sucede que uma série de decisões do STF tem restringido este entendimento de modo a conferir maiores garantias ao exercício da liberdade de informação jornalística.

Após a promulgação da $\mathrm{CF}$, três decisões proferidas pelo STF devem subsidiar o exame desenvolvido neste trabalho. Essas decisões explicitam a proteção dada pela Constituição à crítica jornalística dirigida àqueles que exercem atividade de interesse da coletividade.

\subsection{Agravo Regimental no Agravo de Instrumento N. 690.841 de 2011}

Em 21 de junho de 2011, a Segunda Turma do STF julgou o Agravo Regimental no Agravo de Instrumento n. 690.841. Na oportunidade, afirmou-se o direito de crítica como “prerrogativa político-jurídica de índole constitucional”. A matéria jornalística por meio da

\footnotetext{
${ }_{6}^{5}$ Acerca do assunto, analisando outro problema, leia-se SABINO (2013).

${ }^{6}$ Art. $5^{\circ}$ Todos são iguais perante a lei, sem distinção de qualquer natureza, garantindo-se aos brasileiros e aos estrangeiros residentes no País a inviolabilidade do direito à vida, à liberdade, à igualdade, à segurança e à propriedade, nos termos seguintes:

IV - é livre a manifestação do pensamento, sendo vedado o anonimato;

V - é assegurado o direito de resposta, proporcional ao agravo, além da indenização por dano material, moral ou à imagem;

IX - é livre a expressão da atividade intelectual, artística, científica e de comunicação, independentemente de censura ou licença;

$\mathrm{X}$ - são invioláveis a intimidade, a vida privada, a honra e a imagem das pessoas, assegurado o direito a indenização pelo dano material ou moral decorrente de sua violação;

XIII - é livre o exercício de qualquer trabalho, ofício ou profissão, atendidas as qualificações profissionais que a lei estabelecer;

XIV - é assegurado a todos o acesso à informação e resguardado o sigilo da fonte, quando necessário ao exercício profissional;

Art. 220. A manifestação do pensamento, a criação, a expressão e a informação, sob qualquer forma, processo ou veículo não sofrerão qualquer restrição, observado o disposto nesta Constituição.

$\S 1^{\circ}$ Nenhuma lei conterá dispositivo que possa constituir embaraço à plena liberdade de informação jornalística em qualquer veículo de comunicação social, observado o disposto no art. $5^{\circ}, \mathrm{IV}, \mathrm{V}, \mathrm{X}, \mathrm{XIII}$ e XIV. $\S 2^{\circ}$ É vedada toda e qualquer censura de natureza política, ideológica e artística.
} 
qual eram expostos fatos e "opinião em tom de crítica" excluiria o intuito de ofender e descaracterizaria a ilicitude no comportamento do profissional da imprensa. Estaria caracterizado o regular exercício do direito de informação, motivado por razões de interesse coletivo.

Neste julgado, a situação diferenciada de pessoas públicas foi salientada. Afirmou-se, explicitamente, a possibilidade de crítica jornalística àqueles que exercem atividades de interesse da coletividade em geral, exercentes ou não de cargos oficiais. Por mais duras e veementes que pudessem ser, as críticas às pessoas públicas e às figuras notórias oriundas dos meios de comunicação deixariam de sofre as limitações ordinariamente resultantes dos direitos da personalidade. Esse entendimento reafirmaria o destaque conferido pelo STF à necessidade de preservação da prática da liberdade de informação para o pluralismo de ideias e para o regime democrático (BRASIL, 2011, P. 295-296).

Este julgamento exemplifica importante mudança sob a nova ordem constitucional. Com efeito, a crítica a pessoas públicas ocupantes de cargos oficiais foi claramente assegurada ${ }^{7}$.

\subsection{Agravo Regimental na Medida Cautelar na Reclamação N. 15.243 de 2014}

A Segunda Turma do STF, em 2014, julgou o Agravo Regimental na Medida Cautela na Reclamação n. 15.243. Discutiu-se o eventual descumprimento da decisão proferida na Arguição de Descumprimento de Preceito Fundamental (ADPF) n. 130, que declarou não recepcionada a Lei de Imprensa e afirmou prerrogativas da imprensa.

A decisão do juízo a quo, pelo viés financeiro, por meio de exorbitante condenação, estaria inibindo o exercício regular do jornalismo e impondo verdadeira censura (BRASIL, 2014, p. 2). A Corte entendeu desafiada a autoridade de sua decisão proferida na ADPF n. 130 e, conseguintemente, cabível a reclamação.

A decisão do STF afirmou a possibilidade de crítica jornalística aos que exercem atividades de interesse da coletividade em geral, mesmo sem ostentarem qualquer grau de autoridade - no caso, críticas de um jornalista a um conhecido banqueiro brasileiro.

\footnotetext{
${ }^{7}$ Neste momento, não cabe uma apreciação mais detida sobre a correção do entendimento que estendeu o mesmo tratamento a pessoas públicas que não exercem cargos públicos, que não devem prestar contas à sociedade de qualquer modo. Quando um jornalista faz uma crítica ao trabalho de um ator em uma peça, revela-se nítida a relação com o exercício regular de sua profissão no interesse da sociedade. Em outros casos, não se verifica o interesse público com a mesma clareza e há de se refletir se os direitos da pessoa pública não deveriam prevalecer ( $v . g$., imagem e privacidade).
} 
Entendeu-se que o exercício regular direito de crítica jornalística descaracterizaria a ilicitude objeto de discussão (BRASIL, 2014, p. 11-12).

\subsection{Embargos de Declaração no Recurso Extraordinário com Agravo N. 891.647 de 2015}

Em setembro de 2015, por ocasião do julgamento dos Embargos de Declaração no Recurso Extraordinário com agravo n. 891.647, relatado pelo Ministro Celso de Mello, a Segunda Turma do STF apreciou embargos de declaração recebidos como recurso de agravo em caso no qual se discutia condenação imposta a jornalista pelo crime de injúria (art. 140 do Código Penal) em virtude da ocorrência de "abuso no exercício da liberdade de opinião". Por depender de exame de matéria fático-probatória, insuscetível de análise em recurso extraordinário (Súmula 279/STF), o recurso foi improvido. Em que pese isso, foram feitas algumas observações dignas de nota para o presente trabalho.

Afirmou-se que a livre manifestação do pensamento, embora assegurada constitucionalmente, não teria caráter absoluto. Restrições emergiriam da Constituição, a exemplo da preservação da honra e o respeito à integridade da reputação pessoal. Não seriam amparados opiniões, escritos ou palavras cuja exteriorização configurasse ilícito penal. A liberdade de expressão não traduziria franquia constitucional apta a autorizar o exercício abusivo desse direito (BRASIL, 2015, p. 1-2).

A ementa da decisão embargada apresenta vários aspectos ignorados nas mencionadas decisões proferidas sob a vigência da CR/1891. Faz referência à democracia, à proteção de um mercado de ideias, à proteção das opiniões divergentes (destacando-se, sobre este tema, o julgamento da ADPF n. 187), à liberdade de expressão, de informação e de manifestação do pensamento, a tratado internacional sobre direitos humanos, mas não deixa clara a dimensão institucional da liberdade de comunicação social e, em certa medida, da liberdade de informação.

Ao destacar a falta de um caráter absoluto e ilimitado desta liberdade, concentra-se na negação de uma franquia constitucional ao ilícito praticado em página da internet (blog com mais de cento e cinquenta mil leitores). Neste sentido, mencionou-se o precedente do HC 82.424. Por outro lado, enfatiza que o abuso deveria ser reprimido a posteriori.

Este recente julgamento fez referência à ADPF 130. Desta, transcreveu-se passagem na qual se afirma a possibilidade de restrição às liberdades de expressão e de imprensa baseada em outros valores constitucionais igualmente relevantes - a exemplo da honra, 
imagem, privacidade e personalidade em geral (BRASIL, 2015, p. 18 e 24). Em que pese esta afirmação, é preciso registrar que o julgamento que permitiu biografias não autorizadas (ADI n. 4815) foi decidido por unanimidade ${ }^{8}$.

O órgão julgador a quo enfatizou em sua ementa a possibilidade de indenização pelos danos causados à honra. Chegou a vislumbrar uma discussão próxima de New York Times vs Sullivan ao indicar o debate sobre o caráter absoluto da imprensa, insuscetível de criminalização. Todavia, por não ser a questão discutida no acórdão embargado, foi afastada (a defesa do embargante, no juízo a quo, defendeu a atipicidade da conduta com base na "liberdade de informação e expressão jornalística").

\section{CONCLUSÃO}

Do cotejamento das decisões proferidas pelo STF sob e vigência da CR/1891 e da $\mathrm{CF}$, nota-se uma mudança na orientação da Corte no que concerne à proteção da liberdade de informação jornalística em face dos governantes. Assim como antes, a responsabilidade posterior pelo escrito foi mantida. Todavia, os requisitos para a responsabilização aumentaram.

No passado, a responsabilização criminal estava bem próxima do jornalista; atualmente, a Corte tem feito várias exigências para ter descaracterizado o exercício regular do jornalismo. De outro modo, resta afastada a ilicitude. Além disso, a evolução do entendimento da Corte, sob a influência de normas internacionais ratificadas pelo Estado brasileiro, tem feito a própria responsabilização cível ser objeto de críticas por importar, pela via financeira, em um modo de perseguir e limitar o exercício da atividade jornalística.

Nas decisões analisadas, não se viu a proteção do direito de errar ao veicular informações sobre agentes públicos tal como em New York Times vs Sullivan. Contudo, após a CF, reiteradamente tem sido afirmada a necessidade de proteção da liberdade de informação, o pluralismo de ideias, relativamente a quem exerce atividade de interesse da coletividade. Desse modo, a importância da imprensa para a democracia tem sido analisada de modo mais minucioso.

\footnotetext{
${ }^{8}$ Em outra oportunidade, quando a íntegra dos votos estiver disponível na internet, na página do Tribunal, é preciso analisar se a decisão proferida por ocasião do julgamento das biografias não autorizadas foi coerente com os precedentes do STF.
} 


\section{REFERÊNCIA}

BRASIL. Constituição Política do Império do Brasil de 1824. Disponível em: < http://www.planalto.gov.br/ccivil_03/Constituicao/Constituicao24.htm >. Acesso em: 04 dez. 2015.

BRASIL. Constituição da República dos Estados Unidos do Brasil de 1891. Disponível em: < http://www.planalto.gov.br/ccivil_03/Constituicao/Constituicao91.htm >. Acesso em: 04 dez. 2015.

BRASIL. Constituição da República Federativa do Brasil de 1988. Disponível em: < http://www.planalto.gov.br/ccivil_03/Constituicao/Constituicao.htm >. Acesso em: 04 dez. 2015.

BRASIL. Agravo Regimental no Agravo de Instrumento n. 690.841 de 2011. Disponível em: < http://redir.stf.jus.br/paginadorpub/paginador.jsp?docTP=AC\&docID=625303 >. Acesso em: 06 dez. 2015.

BRASIL. Agravo Regimental na Medida Cautela na Reclamação n. 15.243 de 2014. Disponível em:

$<$ http://redir.stf.jus.br/paginadorpub/paginador.jsp?docTP=TP\&docID=7375422>. Acesso em: 06 dez. 2015.

BRASIL. Embargos de Declaração no Recurso Extraordinário com agravo n. 891.647 de 2015. Disponível em:

$<$ http://redir.stf.jus.br/paginadorpub/paginador.jsp?docTP=TP\&docID=9412755>. Acesso em: 06 dez. 2015.

BRASIL. Habeas corpus n. 3536 de 1914. Disponível em:

<http://www.stf.jus.br/portal/jurisprudencia/listarJurisprudencia.asp?s 1=\%28liberdade+adj4+i mprensa\%29\&pagina $=5 \&$ base $=$ baseAcordaos \&url=http://tinyurl.com/jqbh7nu $>$. Acesso em: 07 dez. 2015.

BRASIL. Habeas corpus n. 4781 de 1919. Disponível em:

<http://www.stf.jus.br/portal/cms/verTexto.asp?servico=sobreStfConhecaStfJulgamentoHisto rico\&pagina=STFdescricaoHC4781>. Acesso em: 06 dez. 2015.

BRASIL. Recurso Criminal n. 491 de 1923. Disponível em: < http://www.stf.jus.br/portal/cms/verTexto.asp?servico=sobreStfConhecaStfJulgamentoHistori co\&pagina=STFdescricaoRCr491>. Acesso em: 06 dez. 2015.

CANOTILHO, José Joaquim Gomes; MOREIRA, Vital. Constituição da República Portuguesa anotada, volume 1. São Paulo: Revista dos Tribunais; Coimbra-PT: Coimbra Editora, 2007.

CAETANO, Marcello. Manual de ciência política e direito constitucional. 6. ed. Coimbra: Almedina, 1998. Tomo I.

DANTAS, Ivo. Direito constitucional comparado: introdução, teoria e metodologia. Rio de Janeiro: Renovar, 2000. 
FISS, Owen. A ironia da liberdade de expressão: Estado, regulação e diversidade na esfera pública. Trad. G. Binenbojm; C. M. Neto. Rio de Janeiro: Renovar, 2005.

LEWIS, Anthony. Liberdade para as ideias que odiamos: uma biografia da Primeira Emenda à Constituição americana. Trad. R. Nucci. São Paulo: Aracati, 2011.

MILTON, John. Areopagítica: discurso pela liberdade de imprensa ao Parlamento da Inglaterra. Tradução Raul de Sá Barbosa. Rio de Janeiro: Topbooks, 1999.

MIRANDA, Jorge. Manual de Direito Constitucional: Vol. IV - Direitos fundamentais. 3. ed. Coimbra: Coimbra Editora, 2000.

MIRANDA, Jorge. Manual de Direito Constitucional: Vol. VII - Estrutura constitucional da democracia. Coimbra: Coimbra Editora, 2007.

MIRANDA, Jorge. Sobre o direito constitucional comparado. In: CLÈVE, Clèmerson Merlin; BARROSO, Luís Roberto (Org.). Direito constitucional: teoria geral da constituição. São Paulo: Revista dos Tribunais, 2011, p. 1267-1287. (Coleção doutrinas essenciais, v. 1)

ROSINA, Mônica Steffen Guise. "Meu trabalho precisa de direito comparado?”. In QUEIROZ, Rafael Mafei Rabelo; FEFERBAUM, Marina (coord). Metodologia jurídica: um roteiro prático para trabalhos de conclusão de curso. 1. ed., 3. tiragem. São Paulo: Saraiva, 2014, p. 123-135. (Série GVlaw)

SABINO, Pedro Augusto Lopes. Liberdade de informação jornalística na Constituição de 1988 e o acesso aos meios de comunicação no exercício do direito de resposta.

[Dissertação de Mestrado] Salvador: Universidade Federal da Bahia, 2013. Disponível em: <https://repositorio.ufba.br/ri/bitstream/ri/12230/1/PEDRO\%20AUGUSTO\%20LOPES\%20S ABINO.pdf $>$. Acesso em: 13 dez. 2015.

SABINO, Pedro Augusto Lopes. Liberdade de informação jornalística: o conceito de notícia e os seus reflexos sobre o direito de resposta. In: Anais do XX Congresso Nacional do

CONPEDI: A Ordem Jurídica Justa: um diálogo Euroamericano. Florianópolis: Fundação Boiteux, 2011. p. 8157-8181.

SILVA, José Afonso da. Um pouco de direito constitucional comparado. São Paulo: Malheiros, 2009.

SOUTO, José Carlos. Suprema Corde dos Estados Unidos: principais decisões. Rio de Janeiro: Editora Lumen Juris, 2008.

VICENTE, Dário Moura. O lugar dos sistemas jurídicos lusófonos entre as famílias jurídicas. In: Revista Brasileira de Direito Comparado. Rio de Janeiro: Instituto de Direito Comparado Luso-Brasileiro, 2008, p. 85-113. 